\title{
Assessment of the Impact of Social Responsibility on Poverty
}

\author{
Egle Jakunskiene
}

Citation: Jakunskiene, E. Assessment of the Impact of Social Responsibility on Poverty. Sustainability 2021, 13 9395. https://doi.org/10.3390/ su13169395

Academic Editors: JinHyo Joseph Yun, Yuri Sadoi, Valentina Della Corte, JungHyun Yoon and Wookjoon Sung

Received: 16 July 2021

Accepted: 10 August 2021

Published: 21 August 2021

Publisher's Note: MDPI stays neutral with regard to jurisdictional claims in published maps and institutional affiliations.

Copyright: (C) 2021 by the author. Licensee MDPI, Basel, Switzerland. This article is an open access article distributed under the terms and conditions of the Creative Commons Attribution (CC BY) license (https:// creativecommons.org/licenses/by/ $4.0 /)$.
Faculty of Public Governance and Business, Mykolas Romeris University, LT-08303 Vilnius, Lithuania; egle.jakunskiene@gmail.com

\begin{abstract}
Being one of the open social innovations of business entities, social responsibility is taking an important role in our society. It not only contributes to the improvement of the financial indicators of business entities, but also has a significant impact on the economic development of countries and the creation of well-being of the society members. The business contribution to environmental and social initiatives influences various economic processes and, at the same time, affects the level of poverty in countries. The purpose of this thesis is to review the concept of social responsibility and its content after the analysis of the scientific literature, and to assess the impact of social responsibility on poverty indicators after an empirical study. The assessment was performed by using the methods of analysis of the scientific literature, mathematical-statistical analysis, comparative analysis, correlation analysis, as well as by studying the presented statistical data at the level of the three Baltic States - Lithuania, Latvia, and Estonia. The conducted research manifested a significant impact of the business units operating in the production sector on the employed people who are at the brink of poverty, by categorizing them by sex, age, and education. The research revealed the negative impact of the business social responsibility that is directed towards the environment field on the poverty rates of older age (65+) residents, due to the installation of new equipment and technologies. Additionally, business investments mostly affect people with secondary, and lower than secondary, education. The influence of the actual pollution amount in the production sector, to ensure the financial stability of the society, was observed. The research results are significant not only to the Baltic region, but to other economies that are seeking to reduce the poverty level in the country, by integrating the business social responsibility as well.
\end{abstract}

Keywords: social responsibility; poverty; economy; society

\section{Introduction}

Open social innovation is a concept that gained prominence in the last decade. Small open social innovations have a chance to make some changes in all global systems, and can be understood as one of the keys to sustainable development. When companies collaborate with multiple actors, such as other companies, startups, universities, or their own employees, it gives better results and has a bigger impact on society. The social responsibility of business entities is one of the instruments of social open innovation, through which a company, with the help of other institutions and individuals, can implement various strategies and make an impact on society.

Poverty alleviation is a complex task for each country, it requires innovative solutions and purposeful cooperation of all the country's institutions, business entities, and members of society. Various performed studies have shown that the market regulation mechanisms that are applied by the state institutions, the activities of international and domestic organizations, etc., are no longer capable of solving the economic issues related to poverty alleviation [1]. Various researchers emphasize that the growing influence of the business sector on the economy and members of society is crucial for economic processes [2] Therefore, in order to alleviate the level of poverty in countries, the contribution of business becomes an integral part of the solutions [3,4]. 
It should be noted that socially responsible business activity is deemed to be one of the main factors defining the responsibility that is accepted by a business, for the impact that it inflicts on the society [5], and, additionally, defining the contribution of a business to the sustainable economic development of countries [6]. Such initiatives affect not only the very business unit, its market, but the entire economy of the country, likewise, contributing to the changes in poverty rates in the countries [7-9]. In any case, an obscurity of the impact of social responsibility to poverty and the complexity of measurement [10], show the necessity to identify the social responsibility fields that have the biggest impact on poverty level reduction in countries. In order to identify these factors and offer appropriate investment areas for a business, related to socially responsible activity that would contribute to poverty reduction in countries, analysis of the scientific literature, correlation analysis, and mathematical-statistical analysis methods were applied. What is more, poverty in countries was assessed by taking into account the age, sex, and education of the employed people who were at the brink of poverty. The research was based on the socially responsible activity of the business units that were operating in the production sector in the Baltic region, oriented to environmental activities. Regarding the socially responsible activities that were identified in the scientific literature, related to the environmental activities, an assessment model construct was drafted, and five hypotheses were formed and verified. The research results revealed the importance and significance of the production sector for the society members, and showed that by investing into socially responsible activities, the businesses would gain an opportunity to reduce poverty in countries.

In order to determine the impact of business social responsibility to poverty, it is appropriate to define the concept, scope, and meaning of social responsibility, as well as the relation between social responsibility and poverty, which is defined in the later stages of the research.

\section{The Concept of Social Responsibility}

Socially responsible activities increasingly influence not only the activities of business entities, but also the formation of the well-being of society. It is observed, in the scientific literature, that the concepts of social responsibility differ depending on the factors that determine the business entity's decision to engage in socially responsible activities, by emphasizing the economic and strategic goals, satisfaction of the needs of the interested parties, social obligations, meeting the expectations of members and employees, mandatory and voluntary involvement, etc. [11]. Various scientists evaluate social responsibility based on different classifications-Carroll (1991) [12] distinguishes between economic, legal, ethical, and philanthropic social responsibility; Schwartz and Carroll (2003) [13] distinguish between economic, legal, and ethical forms of social responsibility; Dahlsrud (2008) [14] evaluates socially responsible activities through interested parties, social, economic, voluntary, and environmental aspects; Aggerholm (2011) [15] assesses social responsibility on the basis of economic, social, and environmental aspects, etc. - which led to the formation of different concepts of social responsibility.

After completing the analysis of the scientific literature, one can observe that the concepts of social responsibility that encompass the environmental activities and socially responsible activity, oriented towards the society, are affected by two main factors-(1) internal and external motivational measures that encompass the implementation of financial objectives $[16,17]$ and the aspiration to fulfil the expectations of business members [18,19]; and (2) optional and mandatory initiatives, by emphasizing the voluntary engagement of the business in socially responsible activity $[20,21]$, and how to incorporate the pressure of state institutions, arising through the legislative framework, into the solution of the social problems in society [22,23]. Thus, these factors not only influence the formation of different concepts of social responsibility, but also encourage more and more business entities to integrate the mechanism of social responsibility in the daily business environment.

By assessing socially responsible activity from the perspective of a business entity, we can distinguish internal and external factors that influence its decision to contribute, 
or not to contribute, to socially responsible activity. According to Friedman (1962) [24], businesses must focus only on achieving financial goals, and not on solving issues that arise in society. Thus, he described social responsibility as a business effort to achieve profit maximization goals. Other scientists have shared the latter opinion, by stating that the profit is the basis of every business, so the business must maintain the traditional business model and focus only on achieving better financial results $[16,25]$. Unlike the latter, the subsequent researchers have emphasized not only the importance of internal incentives, but also the external factors that are directed at the business entity's activities, which force businesses to reorient their traditional ways of operating and focus more on building the well-being of members of the society [26-28]. The consumers, investors, suppliers, financial institutions, and others, expect that businesses will contribute to solving social and environmental issues in society and seek to reduce the negative phenomena arising from the development of its activities. Various researchers, who have studied the factors influencing social responsibility, emphasize that the social responsibility of business entities can be understood as an activity that contributes to solving social and environmental issues in society, and is influenced by various interest groups surrounding the business entity (for instance, financial institutions) [29]. By assuming the social responsibility, and thus meeting the expectations of the members of society, the business entity creates a better image, promotes consumer loyalty, the dissemination of positive information about the business object, etc. [30-34], whose return, in the long run, is reflected in the better financial performance [35]. Thus, the emergence of various internal and external incentives has broadened the concept of the social responsibility of business entities, and further encouraged businesses to consider engaging in socially responsible activities.

It should be noted that the social responsibility of business entities could be understood as mandatory and optional—statutory and voluntary-initiatives. Various authors state that social responsibility has never been accepted voluntarily. It has been a constant act of the market and the legal framework [36], and it is an integral part of social responsibility [37]. By leaving opportunities for businesses to deal with the degree of involvement in socially responsible activities, there is a high probability that businesses will only partially integrate these initiatives into daily activities and the result will not be so significant $[38,39]$. State authorities have the ability to regulate businesses and ensure at least a minimum involvement in socially responsible activities [40], thus ensuring the sustainable development of the economic, financial, environmental, and social environment that is affected by businesses [41]. The shift in the legal framework to social responsibility, has also influenced the emergence of different definitions that are related to this activity. Carroll (1979) [42] has described social responsibility as the aim of a business to create well-being, by taking into account economic, ethical, legal, and discretionary aspects. Friedman (1962) emphasized the legal importance, by treating social responsibility as a business initiative, to maximize profits. According to him, the economic liability cannot be separated from the form of legal liability. Therefore, the social responsibility of business entities is inseparable from legal norms, so various authors emphasize the importance of the legal system in the system of creating social responsibility.

It should be noted that restrictions on social responsibility often do not provide businesses with flexibility in decision making, as the law often lags behind the social developments, including the technological developments and changes in society norms. Therefore, it is very important to integrate the voluntary involvement of businesses in solving social issues in the business mechanism [43]. A business often has higher expectations than complying with the minimum legal requirements [39]. The self-regulatory mechanism and codes of conduct for socially responsible activities, are voluntary and non-legally binding, based solely on the initiative of the business entity itself. Therefore, the business entity's own initiatives, which are often based on reputation building aspirations, only determine the voluntary involvement $[11,44,45]$. The researcher Dahlsrud (2008) described social responsibility as the wish of a business to meet the needs of the surrounding parties, including social, economic, voluntary, and environmental factors. In describing social 
responsibility, McGuire (1963) [46] not only highlighted the compliance of activities with legal and economic factors, but also emphasized the greater involvement of businesses in the creation of public welfare. All this broadened the concept of the social responsibility of business entities, emphasized the importance of volunteering, and of the business entity's own initiatives to contribute to solving issues in society.

Later researches have supplemented the previous concepts by emphasizing the importance of a continuous process. The scientist W. C. Frederick emphasized that social responsibility includes not only greater confidence in businesses, its responses to social issues, adherence to ethical norms, and the creation of global citizenship, but also the millennial continuity of the future that helps to reveal the main challenges of developing social responsibility of business entities [47]. It shows that social responsibility is a long-term and changing phenomenon that expresses itself at different stages of development.

The performed analysis of the scientific literature enables the concept of business social responsibility to be identified (see Figure 1).

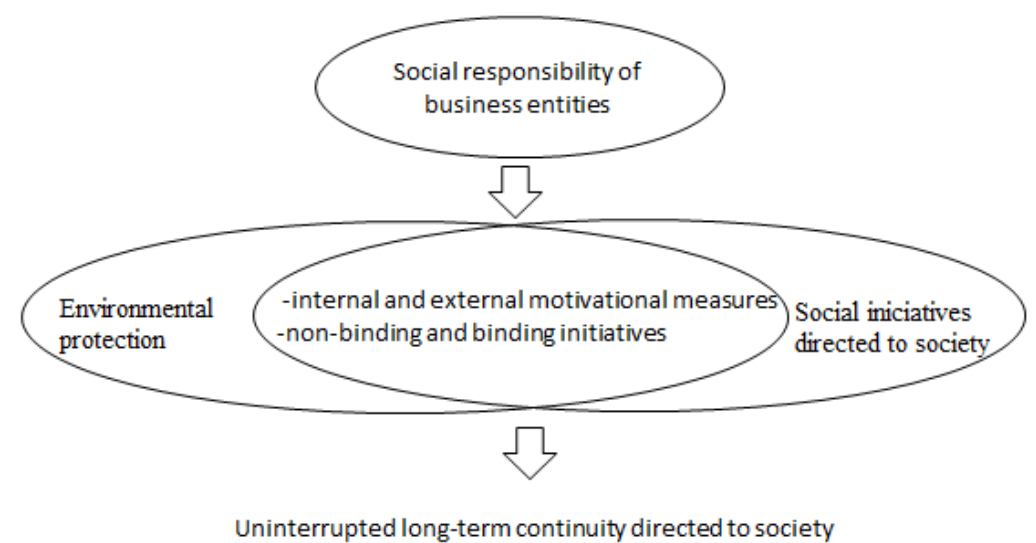

Figure 1. The concept of social responsibility of business entities.

Therefore, social responsibility may be defined as the entirety of the internal business (profit, cost reduction, etc.) and external (the satisfaction of the expectations of the concerned people) objectives, and mandatory (governed by law and regulation) and optional (voluntary) initiatives, manifesting itself through the environmental activities and social activity that is oriented towards society members, likewise, creating a continuous, long-term impact on the society. The correlation between the business social responsibility and poverty, and the interaction of these indicators, are discussed in the later stages of the research.

\section{Links between Social Responsibility and Poverty}

There is an opinion in the economy that businesses constantly contribute to the reduction in economic issues and the assurance of continuous development (increase in employment, continuous investments, etc.) [4]. However, it is noticeable that the strengthening economy, the emerging number of business entities, etc., affect the economic indicators differently. For instance, as the economy strengthens, the number of business entities and investments increase, and the country's poverty rates may also increase. The distribution of the income from economic growth, the priority investment areas for the business entity itself, and the areas that receive the largest financial injections, affect it [48-50]. According to Renouard and Ezvan (2018) [51], businesses need to develop socially responsible initiatives that contribute to poverty reduction, regardless of the benefits to the business entity. Griffin (2017) [52] agrees with this view, arguing that socially responsible business activities can contribute to poverty reduction in a particular economy, thus business focus is important on poverty reduction measures. Thus, the business sector has a significant impact on the changes in poverty rates, so the importance of business 
investment, and the targeted use of its available financial resources, may or may not contribute to poverty alleviation in a given country.

The search for social responsibility, focused on environmental and other social initiatives and poverty alleviation solutions, is a complex task for both developed and developing countries that are characterized by mutual multidimensionality $[53,54]$. Socially responsible activity affects different social groups in a different way, depending on the origin of this activity, i.e., does the business implement social responsibility via the field of environmental activities or social initiatives?

It is noted that social responsibility that manifest via the social activity of a business unit, encompasses the efforts of businesses to contribute, financially and non-financially, to the development of the well-being of different social groups [55-58]. These initiatives encompass the support that is provided to various social groups, e.g., large families, disabled people or those at the brink of poverty [59], the regions devastated by various disasters [60], children education [61], etc. These initiatives are executed by the business unit that is directly engaging, i.e., by directing financial and non-financial (e.g., food) resources to the society members or by engaging various non-governmental organizations [62], or using the contribution of society members to the socially responsible activity via the consumption of certain products, and organizing various social campaigns [63]. Such activity makes a direct impact on the poverty reduction in the country. The conducted research by Clyde and Karnani (2015) [64], and Abugre and Nyuur (2015) [65], revealed that socially responsible activity that is oriented to the support of various social groups, positively affects the poverty rates in the country. According to Okpara and Wynn (2012) [66], business social responsibility is an important criteria that contributes to the reduction in poverty and affects it the most when the financial support is oriented to the activity of institutions that are related to health, social, and education.

Socially responsible business activity that is oriented to the implementation of environmental initiatives affects the poverty rates of countries. The scientific research revealed that ensuring environmental activities and a friendly environment in society are some of the most important factors that contribute to a better supply of food to the society members, constant raise of income, as well as reducing the number of poor society members [67]. On the other hand, poor compliance of the environmental requirements, and only a few business initiatives being oriented to this field, negatively affect the increase in environmental pollution, faster consumption of resources, likewise, contributing to the increase in poverty in a country [68]. Though the last tendencies are best observed in developing countries with a low living standard, developing countries encounter the same problems, because all of them are dependent on natural resources and their exploitation [69]. As a result, business engagement in socially responsible activities that are related to environmental activities, contributes not only to the decrease in ecological trace and improvement of the well-being of the society, but directly affects the poverty rates.

The conducted research by Cleaver and Schreiber (1994) [70], revealed that society is dependent on natural resources and their rapid depletion increases the poverty rates. This means that poverty may be reduced by engaging in the initiative implementation of environmental activities. The later research revealed that the exploitation of natural resources does not guarantee reduced poverty rates, because the latter depends on the current market situation, e.g., employment, level of unemployment, etc. [71]. Oreggia and Garcia (2014) [72] emphasize that the bigger exploitation of resources, e.g., power energy, heating, etc., increases the consumers' costs and, as a consequence, the income and people's possibilities to distribute the financial resources to other needs decrease. All of this contributes to the increase in poverty in countries.

It is noted that not only the rapid depletion of natural resources affects the poverty rates, but the increasing pollution rates also directly affect poverty. The researchers often emphasize that compliance with environmental requirements is the lowest in the countries with the highest poverty level [73,74], and can be associated with air pollution [74], water pollution [75], the increase in gas, causing the greenhouse effect, etc. In the latter, and 
in another conducted research by Anam (2015), the positive correlation between carbon dioxide, income inequality, and the existence of poverty, is noted. This means that when air pollution increases, income inequality, and the poverty rates increase as well. The researchers Liuzzi and Venturi (2021) supplemented their research that was conducted before, by showing that environmental pollution is an inevitable production product that is associated with the appearance of poverty in countries and contributing to the decreasing saving skills of people. Awoke et al. (2016), who performed the research on the scale of African countries, pointed out the increasing water pollution and the importance of implementing social responsibility. According to them, the business has to take responsibility for the existence of environmental problems in society, and contribute to the development of well-being by developing socially responsible activity. Hallegatte and Rozenberg (2017) also disclosed that climate change and the changes in the residential environment, increase the poverty rates. In contrast to the latter, the researcher Khan (2019) [76] showed that it is possible to create a better and cleaner environment in society, by reducing poverty and encouraging the use of renewable energy. This shows that the creation of a better and cleaner environment leads to decreased poverty rates, contributes to the formation of the well-being of the society, changes of their living standard, likewise, it affects the economic development of countries.

Indeed, poverty is closely related to environmental pollution and has a direct mutual dependency, i.e., when the pollution level rises, the number of poor people increases. This is because the increased environmental pollution causes various health disorders among the society members, limited food and drinking water resources, etc. [77], as a result, the costs that are incurred by the society increase and part of the society becomes closer to the brink of poverty. Therefore, the integration of socially responsible activity into the activities of business units, and more attention to the social problems of the society, may contribute to the reduction in poverty in countries.

\section{Methodology}

The scientific literature notes that a business, regardless of its size, engaging in socially responsible activity, positively affects the well-being of the society [78-80]. Though the society often pays attention to the decisions that are made by big companies, of which the society expects more activity in comparison to medium and small business units [81], by amounting to a significant share of the market, these business units also have an important value to the society $[82,83]$. Regarding this, the research was conducted by evaluating the socially responsible activity of all business units, including small and medium business entities.

In addition, the research encompasses all the business units that develop their activity in the production sector. The important activity of this sector led to such a decision, which has a significant impact on the environment and the society [84]. It should be noted that this sector is one of the key sectors in the region of the Baltic States and amounts to more than 22 percent of the state GDP in Estonia, approximately 19 percent in Latvia, and 20 percent in Lithuania (data from the Department of Statistics). Moreover, it should be noted that directives of the European Union specify strategic plans for countries to reduce their environmental pollution, and being one of the biggest sources of environmental pollution, the production sector, experiences big pressure and is forced to engage in socially responsible activities more [85].

The research is based on the assessment of business social responsibility that is oriented to environmental activities. Such a choice was made because social initiatives are frequently associated with the philanthropic activity of a business unit [63], which features irregularities and constant change in the supported social groups. Social initiatives are also associated with the voluntary engagement of businesses in reducing the poverty level in a country and, in contrast, the activity that is associated with the environmental activities does not oblige the business to take part in such an activity. Moreover, it should be pointed out that businesses prefer investing in those fields in which the return may be observed 
during a short period, in the form of cost reduction and profit increase, i.e., the activity that is related to environmental activities.

The object of the research. The impact of the socially responsible activity, oriented to the environmental activities of business units operating in the production sector, on the poverty rates.

The scope of the research. The research encompasses the Baltic countries. It should be noted that the countries comprising the region-Lithuania, Latvia, and Estonia-have many similar features, and share similar historical and cultural development; however, the implementation of different strategies led to the evolved economic and social differences [86]. It should be emphasised, as well, that the level of engagement of a business in the socially responsible activities is not equal in these countries, as a result, their effect on the state economy differs. What is more, businesses implement different strategies in every mentioned country and, consequently, the activities that have a socially responsible basis differ, i.e., businesses invest into those activities that seem the most important, in respect of the features of that country.

In order to conduct the assessment as precisely as possible, the research was conducted based on the statistical data that were provided by Eurostat and the departments of statistics in these countries, and statistical data for the years 2010-2020, by the Organization of Economic Co-operation and Development (OECD).

Selection of variables. The differentiation of business social responsibility and poverty rates is based on the researches that are provided in the scientific literature, by distinguishing the most important fields that are associated with the socially responsible activity that is oriented at the development of the well-being of the society and identifying the members of the society who are at the brink of poverty, according to their distinctive features.

Indicators of business social responsibility. Various authors point out that businesses are one of the main sources of environmental problems in society $[87,88]$. This is precisely why they must bear responsibility for the environmental pollution and integrate the measures of social responsibility in their daily activities, in order to reduce the negative impact on nature and society $[89,90]$. The conducted analysis of the scientific literature enables the separate fields of business social responsibility to be distinguished, of which the implementation has a direct impact on the development of the well-being of the society, and simultaneously affects poverty rates. It is noted that business social responsibility that is oriented to environmental activities, affects the internal and external environment of a business unit. The internal environment of a business encompasses investments in the fields that are related to the reduction in environmental pollution, by including the development and application of equipment and new technologies [89-91], and the creation of additional employment positions that are encouraged by socially responsible activity [92-95]. The external environment of a business unit encompasses the production of products that have an environmental basis and service provision, in order to contribute to the development of the well-being of the society and encourage the social sensibility of the society as well [96-98] (see Table 1).

An activity that performs product production that has a socially responsible basis and service provision, affects the environment and the well-being of the society. The conducted research showed that consumers have a significant impact on the environment; therefore, it is necessary to stress the importance of product development that has an environmental basis [99]. In Suki's (2016) opinion, the comprehension of social value encourages the consumption of products that have a bigger socially responsible basis. Other researchers supplemented previous research and noted that consumers positively assess the information that is related to goods that have an environmental basis, and it encourages increased consumption of the ecologic goods [96] and recyclable products, or the ones that can be recyclable [100]. Therefore, the development of goods and services that have a socially responsible basis, contribute to pollution reduction, the social sensibility of the society, and simultaneously affect poverty rates. 
Table 1. The fields comprising business social responsibility oriented to environmental activities.

\begin{tabular}{|c|c|c|c|c|}
\hline & \multirow{7}{*}{$\begin{array}{l}\text { Goods with environmental } \\
\text { protection basis }\end{array}$} & \multirow{4}{*}{ Type of business entity } & \multirow{2}{*}{$\begin{array}{l}\text { Business entities whose main activity is not related } \\
\text { to environmental activities }\end{array}$} & Total protection and resource management activities \\
\hline & & & & Total environmental protection activities \\
\hline & & & \multirow{2}{*}{$\begin{array}{c}\text { Business entities whose main activity is related to } \\
\text { environmental activities }\end{array}$} & Total protection and resource management activities \\
\hline & & & & Total environmental protection activities \\
\hline & & \multirow{3}{*}{ Area of environmental protection } & \multirow{3}{*}{$\begin{array}{l}\text { Business entities according to the type of } \\
\text { environmental protection }\end{array}$} & Protection of ambient air and climate \\
\hline & & & & Wastewater management \\
\hline & & & & Waste management \\
\hline & \multirow{7}{*}{ Employment } & \multirow{3}{*}{ Type of business entity } & $\begin{array}{l}\text { Business entities whose main activity is not related } \\
\text { to environmental activities }\end{array}$ & Ancillary activities \\
\hline & & & \multirow{2}{*}{$\begin{array}{c}\text { Business entities whose main activity is related to } \\
\text { environmental activities }\end{array}$} & Main activity: services \\
\hline & & & & Main activity: goods \\
\hline & & & & Protection against radiation \\
\hline & & Area of environmental protection & Business entities according to the type of & Protection of ambient air and climate \\
\hline & & & & Wastewater management \\
\hline \multirow[t]{14}{*}{ Environmental Protection } & & & & Waste management \\
\hline & \multirow{13}{*}{ Investments } & Overall investments & Overall investments in environmental protection & Total investments \\
\hline & & \multirow{7}{*}{$\begin{array}{l}\text { Investment in equipment and } \\
\text { technology }\end{array}$} & \multirow{3}{*}{$\begin{array}{l}\text { Investment in equipment according to the type of } \\
\text { environmental protection }\end{array}$} & Wastewater management \\
\hline & & & & Waste management \\
\hline & & & & Other environmental protection activities \\
\hline & & & \multirow{4}{*}{$\begin{array}{l}\text { Investment in technologies according to the type of } \\
\text { environmental protection }\end{array}$} & Protection of ambient air and climate \\
\hline & & & & Wastewater management \\
\hline & & & & Waste management \\
\hline & & & & Other environmental protection activities \\
\hline & & \multirow{5}{*}{$\begin{array}{l}\text { Changes in pollution and use of } \\
\text { resources of business entities }\end{array}$} & \multirow{2}{*}{ Air pollution } & Carbon dioxide \\
\hline & & & & Methane \\
\hline & & & Water use & Water use, according to supply type \\
\hline & & & Waste & Waste of hazardous and non-hazardous goods \\
\hline & & & Soil, groundwater & $\begin{array}{c}\text { Protection and remediation of soil, groundwater and } \\
\text { surface water }\end{array}$ \\
\hline
\end{tabular}


While assessing the production sector of environmental goods and services, not only do business units, with activity that is directly related to the development of ecologic goods and services, attract attention, but also, those business units in which primary activity is not related to them. Various researchers point out the importance of secondary activity (goods and services), by stating that not only the primary, but also the secondary, activity of a business entity may have a fatal impact and determine the results of the research as well [101,102]. After all, such distinction permits a better overview of the business units operating in the production sector, and their contribution to the environmental activities. Additionally, by evaluating the impact of environmental goods and services on poverty, it would be useful to distinguish the goods and services according to the types of impact on the environment. Various scientists note the importance of goods and services to separate fields of environmental activities-air, water pollution, etc. [103,104]. Such distinction allows us to better understand what products and services that solve environmental problems can contribute to poverty reduction in countries.

In the scientific literature, the intermutual relation between social responsibility and employment are emphasized. By investing into socially responsible activities, smoother consumption of renewable resources, businesses create new employment positions, and contribute to increasing employment and reducing poverty rates [105]. Belyaeva (2015) suggests that by investing in socially responsible activities, companies create additional employment positions, and likewise, increase the value and public image of the business unit. The research that was conducted by Robertson (2017) revealed that social responsibility increases the loyalty of employees, work performance, improves the employee's skills, and encourages them to improve themselves, which contributes to the improvement of the financial results of the business unit. It allows for the business unit to allocate more financial resources for the implementation of social responsibility initiatives. As a result, the increasing value of social responsibility urges states to make the decisions that are related to society education and that contribute to enhancing the knowledge of the society about such an activity. This sparks the creation of new employment spots and the decrease in unemployment, the bigger income of the government, and the better education of the society. All this affects the changes in poverty rates in a state. The research that was conducted by other scientists reveals the impact of business social responsibility on individual social groups, e.g., for disabled people who are integrated into the society, by creating additional employment positions for them [93,94]. Consequently, the orientation of businesses to socially responsible activities transforms the internal structure of a business unit, and contributes to the reduction in unemployment in countries and the better integration of individual social groups. By assessing the employment that is influenced by socially responsible activity, the same distinction as with socially responsible goods and services is applied - the categorization, according to the primary and secondary business activity, and the type of problem-solving in society.

The scientists point out the importance of investments in socially responsible activity, which may encompass the total investments (training, education of employees related with environmental protection, etc.), investments in equipment and technologies, and other investments for reducing environment pollution [106]. Schaltegger and Muller (2017) [107] note that investments in the integration of new technologies change the business activity, and contribute to the improvement of environmental activities and the reduction in pollution. Yu et al. (2017) [108] assess the investments in technologies and equipment as one of the most effective ways to reduce the negative impact of businesses directed to the environment and society. Regarding the different amount of investments every business unit puts into equipment updates and the application of new technologies, and taking into account the fact that they may be used to solve specific environmental problems $[109,110]$, the last investments were assessed by taking into account the field of environmental activities. It should be noted, as well, that the importance of investments, and their impact on poverty rates, may be assessed by taking into account the pollution rate changes that 
are affected by investments [111]; therefore, the research is conducted including air, water, etc., pollution rates caused by the business units operating in the production sector.

Poverty rates. The research was conducted by taking into account the rates of employed people and the people who are at the brink of poverty, above 18 years old. The selection of employed people was caused by the fact that the socially responsible activity of business often does not only encompass initiatives that are oriented to the support of social groups, but also the development of the well-being of employees [112,113]. Therefore, the inclusion of employed people into the analysis enables a more precise assessment to be conducted. The selected group was also evaluated by taking into account the sex (male/female), age (18+ and 65+), and education (primary, secondary, higher), in order to determine to who and what age, or education, the business socially responsibility may have the biggest impact. In order to conduct more precise research, the people were evaluated by including an additional variable that determines their possibilities to encounter additional financial costs, i.e., including the rates of society members who are unable to deal with the unexpected financial costs. This enabled more detailed research to be conducted, and one of the most sensitive groups of the society, whose financial stability is on the brink, to be identified.

Forming hypotheses. The performed analysis of the scientific literature enables the following hypotheses that were verified during the research to be distinguished:

Hypothesis 1 (H1). General investments of business units that are oriented to environmental activities positively affect the poverty rates of older women $(65+$ years old) in the region and contribute to their reduction.

Hypothesis 2 (H2). Socially responsible activity, via the increase in general investments, has a positive impact on the society members who struggle with unexpected financial costs.

Hypothesis $3 \mathbf{( H 3 ) . ~ B u s i n e s s ~ e n v i r o n m e n t a l ~ i n v e s t m e n t s ~ t h a t ~ a r e ~ o r i e n t e d ~ t o ~ t h e ~ e q u i p m e n t ~}$ upgrade positively affect the poverty rates of older (65+ years old) residents and contribute to their reduction.

Hypothesis 4 (H4). Business investments, in the development of technologies and integration into daily business activity, negatively affect the poverty rates of the senior (65+ years old) society members and contribute to their increase.

Hypothesis $\mathbf{5}$ (H5). General investments in socially responsible activities mostly decrease the number of people who are at the brink of poverty and have secondary education.

\section{Data Analysis and Results of the Research}

The performed verification of multicollinearity of the statistical data, in order to distinguish only those factors in which intercorrelation is low, i.e., $|\mathrm{r}|<0.3$ and those variables in which correlation with the poverty rates is the strongest $(|r|>0.8)$. Regarding the fact that the measurement expressions of rates differ, a logarithm was applied to the selected rates, which helped to normalize the data and decrease the rate dissipation.

By determining how the distributions of the analyzed rates are distributed, the formal Kolmogorov-Smirnov criterion was applied, by using the level of statistical significance of 0.05 . It was detected that the assumption of normality of the rates was not satisfied, and, as a result, Spearman's correlation coefficient was used, in order to assess the relations between the independent variables, which measure the factors of business social responsibility and poverty level rates of the people of different age, sex, and education. It allowed a generalized model of linear regression (pooled OLS) to be made, where the recorded estimates of the parameters were assessed. The model was drafted according to the following formula: 


$$
\ln \left(Y_{i t}\right)=\alpha+\sum_{k=1}^{p} \beta_{k} \cdot \ln \left(X_{k i t}\right)+\varepsilon_{i t}
$$

- $\quad \alpha$-the shift of log poverty rate (the average of the poverty level);

- $\quad \beta_{k}-k$-the vector of dimension parameters estimates (direction coefficient);

- $Y_{i t}$ - $\log$ poverty rate of the $i^{\text {th }}$ state, at the time moment $t$;

- $\quad X_{k i t}$-the meaning of $k^{\text {th }}$ rate of social responsibility in the $i^{\text {th }}$ state, at the time moment $t$;

- $\quad p$-the number of independent variables;

- $\varepsilon_{i t}$-a model error.

Taking into account that the rate distributions must satisfy the condition of normality, which is assessed as one of the application assumptions of a regression model, the present data were verified in accordance with the Shapiro-Wilk criterion and while determining the $p$ values of the rates. This allowed determining that the assumption of normality is satisfied for all the rates, except for the residents' abilities to encounter unexpected financial costs, because $p<0.05$. The assumption of normality may not have been satisfied, due to the limited take of the provided data.

Moreover, the non-parametric Spearman's correlation coefficient was used to determine the dependency of business social responsibility and intermutual relations of poverty rates. This choice was made due to the fact that not all the data satisfied the condition of normality, and the limited take of the provided data. Determining the $p$ coefficient enabled the rates that have a statistically significant impact on poverty to be identified (when <0.05).

In order to determine the interdependency of the rates, multi- and single- media linear regression models were created. The conducted research showed that business social responsibility activity has a significant impact on the society members struggling to deal with unexpected costs, as well as people who are at the brink of poverty, by categorizing them by age, sex, and education. Eight models in total were created, which were grouped according to their specific features, into four groups.

The group of the society who struggle with coping with financial difficulties, due to unexpected financial costs, is under the primary impact of general business investments into environmental activities (see Table 2).

Table 2. The impact of factors comprising business social responsibility on the society members who cannot experience unexpected financial costs.

\begin{tabular}{lccc}
\hline Variables & Beta & t-Statistics & $p$-Meaning \\
\hline Overall investments (mln., EUR) & -0.685 & -10.22 & 0.000 \\
Methane (tons) & 0.498 & 13.491 & 0.000 \\
Carbon dioxide (tons) & 0.35 & 11.251 & 0.000 \\
\hline
\end{tabular}

The research reveals that the amount of methane gas, carbon dioxide, and general business investments that are oriented to environmental activities, have an impact on the society members who fail at dealing with unexpected financial costs. Due to the activity of business units operating in the production, upon the increase in methane and carbon dioxide, by $1 \%$, the number of people who struggle to cover unexpected financial costs increases by $0.498 \%$ on average, and $0.35 \%$, respectively, in the case of the fixed values of other factors. Such a phenomenon may be associated with the impact that is caused by the environmental pollution, on the health of the society, which requires additional financial resources. It should be noted that the biggest impact on this society group is also conducted via the scope of general investments in environmental activities; when the investments rise by $1 \%$, the number of people who struggle with dealing with unexpected financial costs decreases by $0.685 \%$. This means that general investments in environmental activities contribute to the improvement of the health rates of the society, wider knowledge about this field, improvement of employee qualification, etc., likewise, increasing the well-being of 
the society. The conducted research also reveals that general investments in environmental activities also have the biggest impact on this society group.

The socially responsible activity of the business units operating in the production sector, is related to general investments, the amount of methane gas emitted due to the activity development, and investments in the protection of soil and surface water affect the rates of the employed men who are at the brink of poverty, between 18 and 64 years old (see Table 3).

Table 3. The impact of business social responsibility factors to the employed people who are at the brink of poverty.

\begin{tabular}{lccc}
\hline Variables & Beta & t-Statistics & $p$-Meaning \\
\hline Overall investments (mln., EUR) (age 18+) & -0.542 & -11.10 & 0.000 \\
Overall investments (mln., EUR) (age 65+) & 0.398 & 4.487 & 0.001 \\
Methane (tons) (age 18+) & 0.347 & 3.107 & 0.007 \\
Protection and remediation of soil, groundwater & -0.04 & -0.707 & 0.49 \\
and surface water; (mln., EUR) (age 18+) & & & \\
\hline
\end{tabular}

The results of the research showed that when the amount of methane gas emitted by the production sector increases by $1 \%$, the number of employed men who are at the brink of poverty increases by $0.347 \%$. This means that, by contributing to the reduction in this rate and implementing socially responsible initiatives into its activity, businesses may contribute to poverty reduction among men. The importance of general investments in environmental activities shows that when the investments increase by $1 \%$, the number of men who are at the brink of poverty decreases by $0.542 \%$. The investment into the protection and cleaning of soil and surface water also slightly affects the last rate, and the increase of $1 \%$ causes the decrease in men who are at the brink of poverty, by $0.04 \%$. In contrast to the latter, men of older age, who are older than 65 years old, business environmental activities have a negative impact on the poverty rates. Upon the increase in investments, by $1 \%$, the number of older men who are at the brink of poverty increases by $0.398 \%$. It may be associated with the automatization in different fields, changed work type due to investments, etc.

The impact of socially responsible activity on women's poverty rates, via the increase in general investments, investments in equipment and technologies, and reduction in pollution amount (see Table 4).

Table 4. The impact of business social responsibility factors to the employed women who are at the brink of poverty.

\begin{tabular}{lccc}
\hline Variables & Beta & t-Statistics & $p$-Meaning \\
\hline Overall investments (mln., EUR) (age 18+) & -1.342 & -20.155 & 0.006 \\
Overall investments (mln., EUR) (age 65+) & 1.002 & 19.042 & 0.000 \\
Carbon dioxide (age 18+) & 0.69 & 5.858 & 0.004 \\
Investment in equipment (age 65+) & 1.293 & 22.626 & 0.000 \\
Investment in cleaner technology (age 65+) & 0.53 & 28.619 & 0.000 \\
\hline
\end{tabular}

It is noted that the poverty rates of women between 18 and 64 years old are mostly affected by the general investments in environmental activities, by the business units operating in the production sector, and by the amount of carbon dioxide that is emitted into the environment. The general investments in the environmental initiatives positively affect their financial state, and the increase in business investments, by $1 \%$, decreases the number of residents who are at the brink of poverty, by $1.342 \%$. In addition, the increase in carbon dioxide causes a bigger number of women who are at the brink of poverty, and proportionally to the increase in emitted gas into the atmosphere, by $1 \%$, the poverty rates increase by $0.69 \%$. This means that by investing into socially responsible activities, 
businesses contribute to the reduction in carbon dioxide and poverty among women in the Baltic region.

It is also noted that a positive dependency between the poverty rates of the older women (65+) and business investments into socially responsible activities, i.e., when the number of investments increases, the poverty rates of women increase. General business investments in environmental activities negatively affect older women, and the poverty rates may increase by $1.002 \%$ when business investments change by $1 \%$. When business investments in equipment and technologies increase, an opposite impact is noted as well; when they increased by $1 \%$, the poverty rates would increase by $1.293 \%$ and $0.53 \%$, respectively. It is likely that when installing the latest technologies, additional knowledge is necessary for the employees and, therefore, staff turnover is likely. What is more, the installation of new technologies and equipment means process automatization, and often not all current labor force is necessary to maintain the production. In that case, older employees become disadvantageous.

It should be noted that the general investments of the business units operating in the production sector into socially responsible activities that are related to the environment, affect the society in regards to its education (see Table 5).

Table 5. The impact of business social responsibility to the society members who are at the brink of poverty by education.

\begin{tabular}{lccc}
\hline Variables & Beta & $\mathrm{t}$-Statistics & $p$-Meaning \\
\hline $\begin{array}{l}\text { Overall investments (mln., EUR) } \\
\text { (less than primary, primary and lower secondary } \\
\text { education) }\end{array}$ & -1.058 & -4.49 & 0.004 \\
$\begin{array}{l}\text { Overall investments (mln., EUR) } \\
\text { (Upper secondary and post-secondary non-tertiary }\end{array}$ & -0.103 & -3.48 & 0.013 \\
$\begin{array}{l}\text { education (levels 3 and 4)) } \\
\begin{array}{l}\text { Overall investments (mln., EUR) } \\
\text { (Tertiary education (levels 5-8)) }\end{array}\end{array}$ & -0.368 & -3.507 & 0.013 \\
\hline
\end{tabular}

The created models show that the general costs of the business units operating in the production sector for the environmental activities, have the biggest impact on the people with lower than secondary education. When the general investments in environmental activities increased by $1 \%$, the number of people who are at the brink of poverty decreased by $1.058 \%$. In addition, a slighter, but significant, impact on the people with college-level and university-level education is noted. When the amount of investments increases by $1 \%$, the number of people who are at the brink of poverty decreases by $0.103 \%$ and $0.368 \%$, respectively. This shows that the biggest impact of business social responsibility is on the people with secondary and lower than secondary education, and affects the residents with college-level and university-level education significantly less.

After creating the regression models, one must verify how well these models describe the poverty level rates. In order to reach this goal, the amended determination coefficients were estimated, which showed a mismatch to the poverty rates. It should be noted that the rates of the failure to deal with unexpected financial costs and the rates of women who are at the brink of poverty, between 18 and 64 years, were described the best. These models define the dissemination of $99 \%$ and $97 \%$ of poverty level rates on average, respectively, depending on the change in the rates of business social responsibility (see Table 6). 
Table 6. Model determination coefficients and verification results of autocorrelation.

\begin{tabular}{clcc}
\hline Number & \multicolumn{1}{c}{ Poverty Rate } & $\begin{array}{c}\text { Corrected Coefficient of } \\
\text { Determination (R2) }\end{array}$ & $\begin{array}{c}\text { Statistics of } \\
\text { Durbin-Watson }\end{array}$ \\
\hline 1 & Inability to face unexpected financial expenses & 0.99 & 0.31 \\
2 & Males, 18+ & 0.45 & 2.10 \\
3 & Males, 65+ & 0.85 & 1.88 \\
4 & Females, 18+ & 0.97 & 0.75 \\
5 & Females, 65+ & 0.94 & 0.52 \\
6 & Primary and lower secondary education (levels 0-2) & 0.73 & 1.12 \\
7 & Upper secondary and post-secondary non-tertiary & 0.61 & 0.75 \\
8 & education (levels 3 and 4) & 0.62 & 0.57 \\
\hline
\end{tabular}

It should be noted that the models scarcely define the rates of men who are at the brink of poverty, between the age of 18 and 64 years, and they describe the rate change to be 45 percent on average. Nonetheless, it can be argued that the compatibility of other models with the data is very high and the models describe the rates well. One of the assumptions of regression analysis models is that autocorrelation is not specific for the model errors, i.e., the model errors should not be interrelated, and, for example, the amount of model error in the year 2012 does not have to be dependent on the amount of model error in the year 2011. The Durbin-Watson (DW) criterion was used to verify the autocorrelation of model errors. The obtained results showed that a positive autocorrelation is specific for all the models, except for the men who are at the brink of poverty, between the age of 18 and 64 years. A positive autocorrelation means that if the poverty level was decreasing, e.g., in the year 2011, in 2012, it is likely that it would fall as well. This partly substantiates the theoretic assumptions about the continuity of the social responsibility of business units, and the continuous impact on society.

The performed data analysis enables the correspondence of results to be verified to the formed hypotheses. It is noted that there is a direct dependency between the general investments of business units and the older women (65+) who are at the brink of poverty, i.e., when the amount of investments increase, the number of women who are at the brink of poverty increases. Regarding this, H1 may be rejected. The research showed that business social investments have the biggest impact on the society members who struggle with unexpected financial costs; therefore, $\mathrm{H} 2$ may be accepted. The research also revealed that investments in the equipment and technologies negatively affect the poverty rates of older people and increase them; therefore, H3 may be rejected and H4 may be approved. What is more, the performed analysis showed that general investments in socially responsible activities that are related to the environmental activities positively affect the people having different education, mostly secondary and lower than secondary education. Therefore, H5 may be accepted.

\section{Conclusions}

Business social responsibility that is oriented to the initiatives that are related to the environmental activities encompass the factors directed to the internal and external business environments-internal business environment encompasses the investments in the fields that are related to the reduction in environmental pollution, by including the development and application of equipment and new technologies, and the creation of new employment positions that are encouraged by socially responsible activity; the external environment of a business unit encompasses the production of goods and the provision of services that have an environmental basis, in order to contribute to the creation of the well-being of the society and encourage the social sensibility of the society.

The research revealed that the general investments of business units operating in the production sector into the environmental protection, have the biggest impact on the society members, which positively affects the society members who struggle with unexpected 
financial costs, men and women who are between 18 and 64 years old, and the people having secondary, lower than secondary, college-level, and university-level education. This shows that business social responsibility contributes to the financial improvement of the employed and the people who are at the brink of poverty, which may include initiatives that are related to training, qualification improvement, etc.

It should be noted that general investments negatively affect the poverty rates of older $(65+)$ men and women. It was determined that business investments in the equipment and technologies negatively affect older women, which often means process automatization when the current labor force is not necessary to maintain the necessary production. In that case, older people are in a disadvantageous position.

It is noted that the actual pollution amount that is emitted from the production sector has a significant impact on the fluctuations of the poverty rates. Business investments into environmental activities, and the decrease in the actual decrease in the amount of pollutants, carbon dioxide, and methane, contribute to the reduction in poverty in society and the development of the well-being. In addition, interdependence between investments and methane gas, and investments of business entities and carbon dioxide were found. Also, it was found that environmental pollution mostly affects the financial stability of younger residents. The increase in pollution amount, contributing to the increase in poverty, may be related to the worsening health condition of the society, etc., which becomes the consequence of economic development and the compliance of environmental requirements, and the integration of environmental initiatives in the business activity may contribute to the reduction in poverty and the development of the well-being of the society.

Funding: This research received no external funding.

Data Availability Statement: The data presented in this study are openly available in Eurostat at [https: / / ec.europa.eu/Eurostat, accessed on 10 August 2021], in Organization for Economic Cooperation and Development (OECD) at [https://www.oecd.org/, accessed on 10 August 2021], Department of Statistics in Lithuania [https://www.stat.gov.lt/lt, accessed on 10 August 2021], Department of Statistics in Latvia [https:/ / stat.gov.lv/en, accessed on 10 August 2021], and Department of Statistics in Estonia [https:/ / www.stat.ee/en, accessed on 10 August 2021].

Conflicts of Interest: The autor declares no conflict of interest.

\section{References}

1. Prahalad, C.K. The Fortune at the Bottom of the Pyramid; Wharton School Publishing: Philadelphia, PA, USA, 2004.

2. Dunning, J.H.; Lundan, S.M. Multinational Enterprises and the Globa, Economy, 2nd ed.; Edward Elgar Publishing Limited; Glos, United Kingdom and Edward Elgar Publishing Inc.: Northampton, MA, USA, 2008; pp. 295-338. ISBN 978-84720-122-5.

3. Aluchna, M.; Ragodoo, N. CSR as a tool to fight against poverty: The case of Mauritius. J. Soc. Responsib. 2009, 5, 19-33.

4. Medina-Mundoz, R.D.; Medina-Mundoz, D.R. Corporate social responsibility and poverty alleviation: An integrated research framework. Bus. Ethics 2019, 29, 3-19. [CrossRef]

5. Rashe, A.; Morsing, M.; Moon, J. The changing role of business in global society: CSR and beyond. Corp. Soc. Responsib. Strategy Commun. Gov. 2018, 1-28. [CrossRef]

6. Kolk, A. The social responsibility of international business: From ethics and the environment to CSR and sustainable development. J. World Bus. 2016, 51, 23-34. [CrossRef]

7. Anam, H.S.; Khalid, Z.; Shah, G. The Relationship between Growth-Inequality-Poverty Triangle and Environmental Degradation: Unveiling the Reality. Arab. Econ. Bus. J. 2015, 10, 57-71.

8. Hallegatte, S.; Rozenberg, J. Climate change through a poverty lens. Nat. Clim. Chang. 2017, 7, 250-256. [CrossRef]

9. Liuzzi, D.; Venturi, B. Pollution-induced poverty traps via Hopf bifurcation in a minimal integrated economic-environment model. Commun. Nonlinear. Sci. Number Simulat. 2021, 93, 1-15. [CrossRef]

10. Medina-Mundoz, D.R.; Medina-Mundoz, R.D.; Gutierrez-Perez, F.J. A Sustainable Development Approach to Assessing the Engagement of Tourism Enterprises in Poverty Alleviation. J. Sustain. Dev. 2016, 24, 220-236. [CrossRef]

11. Sarkar, S.; Searcy, C. Zeitgest or chameleon? A quantitative analysis of CSR definitions. J. Clean. Prod. 2016, 135, 1423-1435. [CrossRef]

12. Carroll, A.B. The pyramid of corporate social responsibility: Toward the moral management of organizational stakeholders. J. Bus. Horiz. 1991, 34, 39-48. [CrossRef]

13. Schwartz, M.S.; Carroll, A.B. Corporate social responsibility: A three domain approach. Bus. Ethics Q. 2003, 13, 503-530. [CrossRef] 
14. Dahlsrud, A. How Corporate Social Responsibility is Defined: An Analysis of 37 Definitions. J. Corp. Soc. Responsib. Environ. Manag. 2008, 15, 1-13. [CrossRef]

15. Aggerholm, H.K.; Andersen, S.E.; Thomsen, C. Conceptualizing employer branding in sustainable organizations. Corp. Commun. Int. J. 2011, 16, 105-123. [CrossRef]

16. Davis, K. The case for and against business assumptions of social responsibilities. Acad. Manag. J. 1973, 16, 312-317.

17. Friedman, F. The Social Responsibility of Business Is to Increase Its Profits. In Hartman, Perspectives in Business Ethic; Tata McGraw-Hill Publishing Company Limited: New Delhi, India, 2002.

18. Baden, D.A.; Harwood, I.A.; Woodward, D.G. The effect of buyer pressure on suppliers in SMEs to demonstrate CSR practices: An added incentive or counter productive? Eur. Manag. J. 2009, 27, 429-441. [CrossRef]

19. Rhee, Y.P.; Park, C.; Petersen, B. The effect of local stakeholder pressures on responsive and strategic CSR activities. Bus. Soc. 2018, 60, 582-613.

20. Gatti, L.; Seele, P.; Rademacher, L. Grey zone in-greenwash out. A review of greenwashing research and implications for the voluntary-mandatory transition of CSR. Int. J. Corp. Soc. Responsib. 2019, 4, 1-15. [CrossRef]

21. Gatti, L.; Vishwanath, B.; Seele, P.; Cottier, B. Are we moving beyond voluntary CSR? Exploring theoretical and managerial implications of mandatory CSR resulting from the new Indian companies act. J. Bus. Ethics 2019, 160, 961-972. [CrossRef]

22. Scheuch, A. Soft law requirements with hard law effects? The influence of CSR on corporate law from a German perspective. In Globalisation of Corporate Social Responsibility and Its Impact on Corporate Governance; du Plessis, J., Varottil, U., Veldman, J., Eds.; Springer: New York, NY, USA, 2017; ISBN 978-3-319-69127-5.

23. Situngkir, R. Legal analysis on the implementation on the implementation of corporate social and environmental responsibility by regional governments. NOMOI Law Rev. 2020, 1, 147-169.

24. Friedman, M. Capitalism and Freedom; University of Chicago Press: Chicago, IL, USA, 1962.

25. Hayek, F.A. The Corporation in a Democratic Society: In Whose Interest Ought It and will It Be Run? Ansoff, H.I., Ed.; Business Strategy, Penguin Books: London, UK, 1969.

26. Ajina, A.S.; Japutra, A.; Nguyen, B.; Alwi, S.F.S.; Al-Hajla, A. The importance of CSR initiatives in building customer support and loyalty. Evid. Saudi Arab. Asia Pac. J. Mark. Logist. 2018, 31, 691-713. [CrossRef]

27. Longinos, M.; Martin, P.J.; Rubio, A. Doing good and different! The mediation effect on innovation and investment on the influence of CSR to competitiveness. Corp. Soc. Responsib. Environ. Manag. 2017, 24, 159-171.

28. Tang, L.; Gekara, V. The importance of customer expectations: An analysis of CSR in container shipping. J. Bus. Ethics 2020, 165, 383-393. [CrossRef]

29. Boiral, O.; Heras-Saizarbitoria, I.; Tesa, F. SA8000 as CSR-washing? The role of stakeholders pressures. Corp. Soc. Responsib. Environ. Manag. 2017, 24, 57-70. [CrossRef]

30. Contini, M.; Annunziata, E.; Rizzi, F.; Frey, M. Exploring the influence of corporate social responsibility (CSR) domains on consumers loyalty: An experiment in BRICS countries. J. Clean. Prod. 2020, 247, 1-10. [CrossRef]

31. Huang, M.H.; Cheng, Z.H.; Chen, I.C. The importance of CSR in forming customer-company identification and long-term loyalty. J. Serv. Mark. 2017, 31, 63-72. [CrossRef]

32. Skordoulis, M.; Ntanos, S.; Kyriakopoulos, G.L.; Arabatzis, G.; Galatsidas, S.; Chalikias, M. Environmental Innovation, Open Innovation Dynamics and Competitive Advantage of Medium and Large-Sized Firms. J. Open Innov. Technol. Mark. Complex. 2020, 6, 195. [CrossRef]

33. Tjahjadi, B.; Soewarno, N.; Hariyati, H.; Nafidah, L.N.; Kustiningsih, N.; Nadyaningrum, V. The Role of Green Innovation between Green Market Orientation and Business Performance: Its Implication for Open Innovation. J. Open Innov. Technol. Mark. Complex. 2020, 6, 173. [CrossRef]

34. Turban, D.B.; Greening, D.W. Corporate Social Performance And Organizational Attractiveness To Prospective Employees. Acad. Manag. J. 1997, 40, 658-672.

35. Xie, X.; Jia, Y.; Meng, X.; Li, C. Corporate social responsibility, customer satisfaction, and financial performance: The moderating effect of the institutional environment in two transition economies. J. Clean. Prod. 2017, 150, 26-39. [CrossRef]

36. McBarnet, D. Corporate social responsibility beyond law, through law, for law. U Edinb. Sch. Law Work. Pap. 2009, 3, 1-63. [CrossRef]

37. Chinkin, C.M. The Challenge of Soft Law: Development and Change in International Law. Int. Comp. Law Q. Oct. 1989, 38, 850-866. [CrossRef]

38. Boeger, N.; Murray, R.; Villiers, C. Perspectives on Corporate Social Responsibility; Edward Elgar Publishing: Glos, UK, 2008; ISBN 978-1-84720-561-2.

39. Yan, M. Corporate Social Responsibility versus Shareholder Value Maximization: Through the Lens of Hard and Soft Law. Northwestern J. Int. Law Bus. 2019, 40, 47-86.

40. Boyle, A.; Chinkin, C. The Making of International Law, Foundations of Public International Law; Oxford University Press: New York, NY, USA, 2007; ISBN 978-0-19-921379-5.

41. Bijlmakers, S. Corporate Social Responsibility, Human Rights, and the Law; Routledge Research in Sustainalility and Business: Abingdon, UK; Routledge: New York, NY, USA, 2019; ISBN 978-1-351-17192-2.

42. Carroll, A.B. A Three-Dimensional Conceptual Model of Corporate Performance. Acad. Manag. Rev. 1979, 4, 497-505. [CrossRef] 
43. Scherer, A.G.; Palazzo, G. The New Political Role of Business in a Globalized World: A Review of a New Perspective on CSR and its Implications for the Firm, Governance, and Democracy. J. Manag. Stud. 2011, 48, 899-931. [CrossRef]

44. Arevalo, J.A.; Aravind, D. Strategic Outcomes in voluntary CSR: Reporting economic and reputational benefits in principles-based initiatives. J. Bus. Ethics 2017, 144, 201-217. [CrossRef]

45. Garcia-Sanchez, I.M.; Garcia-Sanchez, A. Corporate Social Responsibility during COVID-19 Pandemic. J. Open Innov. Technol. Mark. Complex. 2020, 6, 126. [CrossRef]

46. McGuire, J.W. Business and Society; McGraw-Hill: New York, NY, USA, 1963.

47. Weber, J.; Wasieleski, D.M. Corporate Social Responsibility, BusinessESociety 360; Emerald Publishing Limited: Bingley, UK, 2018; ISBN 978-1-78754-260-0.

48. Greve, B. Poverty: The Basics; Routledge: New York, NY, USA; London, UK, 2019; ISBN 978-0-367-27634-8.

49. Kao, T.Y.; Chen, J.C.H.; Wu, J.T.B.; Yang, M.H. Poverty reduction through empowerment for sustainable dvelopment: A proactive strategy of corporate social responsibility. Corp. Soc. Responsib. Environ. Manag. 2016, 23, 140-149. [CrossRef]

50. Wang, Z.; Zhang, B.; Wang, B. Renewable energy consumption, economic growth and human development index in Pakistan. Evidence from simultaneous equation model. J. Clean. Prod. 2018, 184, 1081-1090. [CrossRef]

51. Renouard, C.; Ezvan, C. Corporate social responsibility towards human development: A capabilities framework. J. Bus. Ethics: A Eur. Rev. 2018, 27, 144-155. [CrossRef]

52. Griffin, J.J. Tracing stakeholder terminology then and now: Convergence and new pathways. J. Bus. Ethics A Eur. Rev. 2017, 26, 326-346. [CrossRef]

53. Alvarez, S.A.; Barney, J.B.; Newman, A.M.B. The Poverty Problem and the Industrialization Solution. Asia Pac. J. Manag. 2015, 32, 23-37. [CrossRef]

54. Masron, T.A.; Subramaniam, Y. Does poverty cause environmental degradation? Evidence from developing countries. J. Poverty 2019, 23, 44-64. [CrossRef]

55. Chen, X.; Huang, R.; Yang, Z.; Dube, L. CSR types and the moderating role of corporate competence. Eur. J. Mark. 2018, 52, 1358-1386. [CrossRef]

56. Dembek, K.; Sivasubramaniam, N.; Chmielewski, D.A. A systematic review of the bottom/base of the pyramid literature review: Cumulative evidence and future directions. J. Bus. Ethics 2019, 165, 365-382. [CrossRef]

57. Morvaridi, B. Does Sub-Saharan Africa need capitalist philantrophy to reduce poverty and achieve food security? Rev. Afr. Political Econ. 2016, 43, 151-159. [CrossRef]

58. Sert, S.; Garrone, P.; Merlacini, M.; Perego, A. Corporate food donations: Altruism, strategy or cost saving? Br. Food J. 2018, 120, 1628-1642. [CrossRef]

59. Kotilainen, J.; Prokhorova, E.; Sairinen, R.; Tiainen, H. Corporate social responsibility of mining companies in Kyrgyzstan and Tajikistan. J. Resour. Policy 2015, 45, 202-209. [CrossRef]

60. Behl, A.; Dutta, P. Social and financial aid for disaster relief operations using CSR and crowdfunding. Benchmarking Int. J. 2020, 27, 732-759. [CrossRef]

61. Sengupta, M. Corporate Social Responsibility in India, Cases and Developments After the Legal Mandate; Springer International Publishing: Cham, Switzerland, 2018; ISBN 978-3-319-41781-3.

62. Lodsgard, L.; Aagaard, A. Creating value through CSR across company functions and NGO collaborations: A Scandinavian cross-industry case study. Scand. J. Manag. 2017, 33, 162-174. [CrossRef]

63. Lichtenstein, D.R.; Drumwright, M.E.; Braig, B.M. The Effect of Corporate Social Responsibility on Customer Donations to Corporate-Supported Nonprofits. J. Mark. 2004, 68, 16-32. [CrossRef]

64. Clyde, P.; Karnani, A. Improving Private Sector Impact on poverty Alleviation: A Cost-Based Taxonomy. J. Calif. Manag. Rev. 2015, 57, 20-35. [CrossRef]

65. Abugre, J.B.; Nyuur, R.B. Organizations' commitment to and comunication of CSR initiatives: Insights from Ghana. J. Soc. Responsib. 2015, 11, 161-178. [CrossRef]

66. Okpara, J.O.; Wynn, P.M. Stakeholders' Perceptions About Corporate Social Responsibility: Implications for Poverty Alleviation. Thunderbird Int. Bus. Rev. 2012, 54, 91-103. [CrossRef]

67. Schleicher, J.; Cchaafsma, M.; Burgess, N.D.; Sandbrook, C.; Danks, F.; Cowie, C.; Vira, B. Poorer without it? The neglcted role of the natural environment in poverty and wellbeing. J. Sustain. Dev. 2018, 26, 83-98. [CrossRef]

68. Rai, J. Understanding poverty-environment relationship from sustainable development perspectives. J. Geogr. Environ. Earth Sci. Int. 2019, 18, 1-13. [CrossRef]

69. Danish, B.M.A.; Mahnood, N.; Zhang, J.W. Effect of natural resources, renewable energy and economic development on $\mathrm{CO}_{2}$ emissions in BRICS countries. Sci. Total. Environ. 2019, 678, 632-638. [CrossRef] [PubMed]

70. Cleaver, K.M.; Schreiber, G.A. Reversing the Spiral: The Population, Agriculture, and Environmental Nexus in Sub-Saharan Africa; World Bank Group: Washington, DC, USA, 1994.

71. Barbier, E.B. Poverty, development, and environment. J. Environ. Dev. Econ. 2010, 15, 635-660. [CrossRef]

72. Oreggia, R.E.; Garcia, Y.R.A. Income and Energy Consumption in Mexican Households. World Bank Policy Research Working Paper No. 6864. 2014. Available online: file:/ / C:/Users/pc/Downloads/SSRN-id2436659.pdf (accessed on 10 August 2021).

73. Baloch, M.A.; Khan, S.U.D.; Ulucak, S. Poverty and vulnerability of environmental degradation in Sub-Saharan African countries: What causes what? Struct. Chang. Econ. Dyn. 2020, 54, 143-149. [CrossRef] 
74. Osseiran, N.; Chriscaden, K. Air Pollution Levels Rising in Many of the World's Poorest Cities; WHO: Geneva, Switzerland, 2016.

75. Awoke, A.; Beyene, A.; Kloos, H.; Goethals, P.L.M.; Triest, L. River Water Pollution Status and Water Policy Scenario in Ethiopia: Raising Awareness for Better Implementation in Developing Countries. J. Environ. Manag. 2016, 58, 694-706. [CrossRef]

76. Khan, S.A.R. The nexus between carbon emissions, poverty, economic growth, and logistics operations-empirical evidence from southeast Asian countries. Environ. Sci. Pollut. Res. 2019, 26, 13210-13220. [CrossRef]

77. Lessard, L.; Alcala, E.; Capitman, J.A. Pollution, Poverty, and Potentially Preventable Childhood Morbidity in Central California. J. Pediatrics 2016, 168, 198-204. [CrossRef]

78. Dias, A.; Rodrigues, L.L.; Craig, R.; Neves, M.E. Corporate social responsibility disclosure in small and medium-sized entities and large companies. J. Soc. Responsib. 2019, 15, 137-154. [CrossRef]

79. Hadj, T.B. Effects of corporate social responsibility towards stakeholders and environmental management on responsible innovation and competitiveness. J. Clean. Prod. 2020, 250,1-10. [CrossRef]

80. Zaefarian, R.; Tasavori, M.; Ghauri, P.N. A Corporate Social Enterpreneurship Approach to Market-Based Poverty Reduction. J. Emerg. Mark. Financ. Trade 2015, 51, 320-334. [CrossRef]

81. Gaither, M.B.; Augustin, L.; Schulz, M. Delineating CSR and social change: Querying corporations as actors for social good. J. Public Relat. Inq. 2018, 7, 45-61. [CrossRef]

82. Araque, B.Y.; Hernandez, J.P.S.I.; Broncano, S.G.; Esevez, P.J. Corporate social responsibility in micro-, small-and medium-sized enterprises: Multigroup analysis of family vs. Nonfamily firms. J. Bus. Res. 2021, 124, 581-592. [CrossRef]

83. Dey, P.K.; Petridis, N.E.; Petridis, K.; Malesios, C.; Nicon, J.D.; Ghosh, S.K. Environmental management and corporate social responsibility practices of small and medium-sized enterprises. J. Clean. Prod. 2018, 195, 687-702. [CrossRef]

84. Torugsa, N.A.; O’Donohue, W.; Hecker, R. Capabilities, Proactive CSR and Financial Performance in SMEs: Empirical Evidence from an Australian Manufacturing Industry Sector. J. Bus. Ethics 2011, 109, 483-500. [CrossRef]

85. European Commission Kick-Starting the Journey Towards a Climate-Neutral EUROPE by 2050. EU Climate Action Progress Report. 2020, pp. 1-52. Available online: https:/ / ec.europa.eu/clima/sites/clima/files/strategies/progress/docs/com_2020_777_en.pdf (accessed on 10 August 2021).

86. Poissonnier, A. The Baltics: Three Coutries, One Economy? Eur. Econ. Econ. Brief 2017, 24, 1-10.

87. Buchholz, R.A. Principles of Environmental Management: The Greening of Business, 2nd ed.; Prentice-Hall, Inc.: Hoboken, NJ, USA, 1998; ISBN 0136848958.

88. Zhu, L.; Hao, Y.; Lu, Z.N.; Wu, H.; Ran, Q. Do economic activities cause air pollution? Evidence from China's major cities. J. Sustain. Cities Soc. 2019, 49, 1-10. [CrossRef]

89. Ihlen, O. Business and Climate Change: The Climate Response of the World's 30 Largest Corporations. J. Environ. Commun. 2009, 3, 244-262. [CrossRef]

90. Ramanathan, N. Quality-based management for future-ready corporations serving society and planet. J. Total. Qual. Manag. Bus. Excell. 2021, 32, 541-557. [CrossRef]

91. Pan, X.; Sinha, P.; Chen, X. Corporate social responsibility and eco-innovation: The triple bottom line perspective. J. Corp. Soc. Responsib. Environ. Manag. 2020, 28, 214-228. [CrossRef]

92. Belyaeva, Z. CSR in the Russian aviation industry: The winds of change. J. Strateg. Dir. 2015, 31, 7-9. [CrossRef]

93. Csillag, S.; Gyori, Z. Is There a Place for Me? Employment of People with Disabilities as Part of CSR Strategy; International Academic Conference, Fourth Eddition, Oportunities and risks in the contemporary business environment; Strategica: Bucharest, Romania, 2016; pp. 860-872. ISBN 978-606-749-181-4.

94. Miethlich, B.; Šlahor, L. Employment of persons with disabilities as a corporate social responsibility initiative: Necessity and variants of implementation. In Proceedings of the CBU International Conference on Innovations in Science and Education, Prague, Czech Republic, 21-23 March 2018; pp. 350-355.

95. Robertson, J.A. Educating the workforce through CSR. Ann. Soc. Responsib. 2017, 3, 70-71. [CrossRef]

96. Alamsyah, D.P.; Othman, N.A.; Mohammed, H.A.A. The awareness of environmentally friendly products: The impact of green advertising and green brand image. J. Manag. Sci. Lett. 2020, 10, 1961-1968. [CrossRef]

97. Huang, C.H.; Lin, T.H.; Lai, M.C.; Lin, T.L. Environmental consciousness and green customer behavior: An examination of motivation crowding effect. Int. J. Hosp. Manag. 2014, 40, 139-149. [CrossRef]

98. Suki, N.M. Consumer environmental concern and green product purchase in Malaysia: Structural effects of consumption values. J. Clean. Prod. 2016, 132, 204-214. [CrossRef]

99. Ivanova, D.; Stadler, K.; Steen-Olsen, K.; Wood, R.; Vita, G.; Tukker, A.; Hertwich, E.G. Environmental Impact Assessment of Household Consumption. J. Ind. Ecol. 2015, 20, 526-536. [CrossRef]

100. Sun, H.; Teh, P.L.; Linton, J.D. Impact of environmental knowledge and product quality on student attitude toward products with recycled/remanufactured content: Implications for environmental education and green manufacturing. J. Bus. Strategy Environ. 2018, 27, 935-945. [CrossRef]

101. Ghiani, E.; Galici, M.; Mureddu, M.; Pilo, F. Impact on Electricity Consumption and Market Pricing of Energy and Ancillary Services during Pandemic of COVID-19 in Italy. J. Energ. 2020, 13, 1-19.

102. Gomes, R.; Tirole, J. Missed sales and the pricing of ancillary goods. Q. J. Econ. 2018, 133, 2097-2169. [CrossRef] 
103. Msosa, S.K.; Govender, J.P. Environmental Impact and CSR Responsibilities. In Opportunities and Pitfalls of Corporate Social Responsibility, CSR, Sustainability, Ethics, Governance; Mugova, S., Sachs, P., Eds.; Springer: Berlin/Heidelberg, Germany, 2019; ISBN 978-3-030-17101-8.

104. Zugravu-Soilita, N. The impact of trade in environmental goods on pollution: What are we learning from the -transition economies' experience? J. Environ. Econ. Policy Stud. 2018, 20, 785-827. [CrossRef]

105. Kamoun, M.; Abdelkafi, I.; Ghorbel, A. Does Renewable Energy Technologies and Poverty Affect the Sustainable Growth in Emerging Countries? J. Knowl. Econ. 2020, 11, 865-887. [CrossRef]

106. Hasanbeigi, A.; Price, L. A technical review of emarging technologies for energy and water efficiency and pollution reduction in the textile industry. J. Clean. Prod. 2015, 95, 30-44. [CrossRef]

107. Schaltegger, S.; Muller, K. Calculating the True Profitability of Pollution Prevention 1. In The Green Bottom Line; Routledge: London, UK, 2017.

108. Yu, S.; Zheng, S.; Gao, S.; Yang, J. A multi-objective decision model for investment in energy savings and emission reductions in coal mining. Eur. J. Oper. Res. 2017, 260, 335-347. [CrossRef]

109. Chen, L.; Wang, L.; Wu, X.; Ding, X. A process-level water conservation and pollution control performance evaluation tool of cleaner production technology in textile industry. J. Clean. Prod. 2017, 143, 1137-1143. [CrossRef]

110. Zheng, Y.; Peng, J.; Xiao, J.; Su, P.; Li, S. Industrial structure transformation and provincial heterogeneity characteristics evolution of air pollution: Evidence of a threshold effect from China. J. Atmos. Pollut. Res. 2020, 11, 598-609. [CrossRef]

111. Zhang, Z.; Zhao, W. Research on Financial Pressure, Poverty Governance, and Environmental Pollution in China. J. Sustain. 2018, 10, 1834. [CrossRef]

112. Ahmed, M.; Zehou, S.; Raza, S.A.; Qureshi, M.A.; Yousufi, S.Q. Impact of CSR and environmental triggers on employee green behavior: The mediating effect of employee well-being. Corp. Soc. Responsib. Environ. Manag. 2020, 27, 2225-2239. [CrossRef]

113. Kim, H.; Rhou, Y.; Topcuoglu, E.; Kim, Y.G. Why hotel employees care about Corporate Social Responsibility (CSR): Using need satisfaction theory. Int. J. Hosp. Manag. 2020, 87, 1-8. [CrossRef] 